\title{
SME INTERNATIONALIZATION: A DESCRIPTIVE REVIEW OF NONTRADITIONAL APPROACHES
}

\author{
INTERNACIONALIZACIÓN DE LAS PYME: UNA REVISIÓN DESCRIPTIVA \\ DE LOS ENFOQUES NO TRADICIONALES
}

\author{
Adil Munima ${ }^{\mathrm{a}}$ Michel Rod $^{\mathrm{b} *} \cdot$ Alia El Banna ${ }^{\mathrm{c}}$ \\ Classification: Conceptual paper \\ Received: April 27, 2020 / Revised: May 16, 2020 / Accepted: May 18, 2020
}

\begin{abstract}
The literature surrounding SME internationalization is still in its infancy but growing rapidly as SMEs become prominent in global markets. This paper outlines that, although stage theories of internationalization have dominated the literature in the past, newer theories deviate from this line of thinking. Notably, theories originating from the field of entrepreneurship, such as effectuation and bricolage, have been found to be quite informative in explaining the behaviour of SMEs, yet they are greatly underrepresented in the internationalization literature. Our study critically reviews the SME internationalization literature and highlights concepts such as resource scavenging, social capital, muddling through, and dynamic experimental internationalization - all reflective of a nontraditional pattern of thinking. These approaches explain the spontaneity and improvisation that is inherent in a lot of SME internationalization. We find that 'nontraditional' approaches to internationalization hold great value for both academics and professionals. Our findings reveal that many of the nontraditional approaches are still within the early stages of development, and thus require greater theoretical and empirical analysis. This study forms a foundational basis upon which future researchers can build a stronger understanding of nontraditional SME internationalization. For SMEs contemplating internationalizing, this study provides key insights into the complex process of engaging with foreign markets. Nontraditional approaches introduce strategies that SMEs can employ in both foreign market selection and foreign market entry processes.
\end{abstract}

Keywords: Effectuation, SME, internationalization, nontraditional theory, strategic processes.

\section{Resumen}

La literatura sobre la internacionalización de las pyme todavía está en pañales, pero está creciendo rápidamente a medida que las pyme se vuelven prominentes en los mercados mundiales. Este artículo describe que, aunque las teorías de la internacionalización han dominado la literatura en el pasado, las nuevas teorías se desvían de esta línea de pensamiento. En particular, se ha encontrado que las teorías que se originan en el campo del emprendimiento, como la realización y el bricolaje, son bastante informativas para explicar el comportamiento de las pyme, pero están muy poco representadas en la literatura de internacionalización. Este artículo revisa críticamente la literatura de internacionalización de las pyme y destaca conceptos tales como la recolección de recursos, el capital social, la confusión y la internacionalización experimental dinámica, todo reflejo de un patrón de pensamiento no tradicional. Estos enfoques

University of Toronto, Faculty of Law. Toronto, Canada. Email: adil.munim@gmail.com

University of New Brunswick, Faculty of Business. Canada. Email: mrod@unb.ca. * Corresponding author.

Ocean Pulser. Madrid, Spain. Email: aliaelbanna@oceanpulser.com 
explican la espontaneidad e improvisación que es inherente a gran parte de la internacionalización de las pyme. Descubrimos que los enfoques "no tradicionales" de la internacionalización tienen un gran valor tanto para académicos como para profesionales. Nuestros hallazgos revelan que muchos de los enfoques no tradicionales todavía se encuentran en las primeras etapas de desarrollo y, por tanto, requieren un mayor análisis teórico y empírico. Este estudio forma una base fundamental sobre la cual los futuros investigadores pueden construir una comprensión más sólida de la internacionalización de las pyme no tradicional. Para las pyme que contemplan la internacionalización, este estudio proporciona información clave sobre el complejo proceso de interacción con los mercados extranjeros. Los enfoques no tradicionales introducen estrategias que las pyme pueden emplear tanto en la selección del mercado extranjero como en los procesos de entrada al mercado extranjero.

Palabras clave: eficacia, pyme, internacionalización, teoría no tradicional, procesos estratégicos.

\section{Introduction}

Over the last few decades, the field of research surrounding small to medium-sized enterprise (SME) internationalization has grown vastly (Elbanna, Hsieh \& Child, 2020; Hsieh et al., 2019; Paul, 2020). As an increasing number of small firms enter foreign markets, the need for a concrete analysis of this process becomes more apparent (Li, Qian, Qian \& Lu, 2018). Researchers have focused on developing a clearer understanding of how SMEs approach and proceed through the complex process of internationalization, particularly with respect to the resource constraints that they face and the nature of the inter-organizational linkages that they develop (Bradley, Meyer \& Gao, 2006). This paper presents a critical review of the small to medium-sized enterprise (SME) internationalization literature. In examining the literature, we find that several approaches towards SME internationalization have emerged since the 1980s.

The study is framed in a specific manner, examining nontraditional internationalization patterns that have been identified by researchers. The paper begins with a brief examination of the traditional, stage models of internationalization - including the Uppsala model - that dominated much of the literature prior to the turn of the century. These models were mainly applied in the context of the internationalization of larger firms with some extension to the context of SMEs. However, we make mention of several studies that have demonstrated the inapplicability of stage models to the context of SME internationalization. The purpose of this paper is not to criticize the stage models, but rather to present the models of SME internationalization that follow an inherently different pattern of thinking. We find that SME internationalization approaches are better defined by a less rigid and step-wise pattern of thinking. Some of these approaches originate in other fields, such as entrepreneurship. Entrepreneurs and SMEs often face similar resource constraints and uncertain/unpredictable situations. Thus, the approaches of effectuation and bricolage are introduced. Empirical evi- dence is cited to demonstrate that these entrepreneurial approaches have been documented in the foreign market entry processes of SMEs. Subsequently, we present four new approaches or theoretical underpinnings to SME internationalization. These include: resource scavenging; social capital; muddling-through; and dynamic experimental internationalization. Though many of these were first introduced in other fields, their application to SME internationalization has been documented in the last decade. We present empirical evidence that illustrates this for each approach introduced. Furthermore, we provide a rudimentary comparison of these approaches to delineate any (dis)similarities. We note that there exist three underlying commonalities that connect the six internationalization approaches presented in this paper: serendipity, social networks, and improvisation. The paper concludes with an overview of findings and implications for both academics and professionals.

\section{Literature Review}

To conduct a comprehensive (but non-systematic) literature review, we examined peer-reviewed sources from a variety of journals using Google Scholar, Emerald Management, EBSCO, ABI/Inform and Business Source Complete databases. With the earliest definitions of relevant concepts dating back to 1970, our research was limited to a timeframe of articles published between 1970 and 2020. All potential journals were considered, irrespective of field of study; though most were published in the fields of marketing, management, and entrepreneurship. Some key publications include the Journal of International Business Studies, Journal of Business Venturing, Management International Review, the International Business Review, Entrepreneurship Theory \& Practice, and the Journal of Small Business and Enterprise Development with additional reference to business-to-business (B2B) journals such as Industrial Marketing Management and Journal of Business and Industrial Marketing. This variety in publications also allowed us to ensure 
that our study was global in terms of geographic scope. The search for relevant sources was extensive, but by no means exhaustive. It is important to note that this is not a 'Systematic Literature Review' (SLR), although we were guided on some level, by published SLRs (Costa, Soares \& Sousa, 2016; Ribau, Moriera \& Raposo, 2018) since the goal was to be thorough without necessarily subscribing to all the rules and rigour associated with systematic literature reviews. Thus, despite being non-systematic, there was attention paid to appropriate search (seeking to identify the most significant studies published in higher ranked outlets - see below), appraisal (evaluated based on contribution), synthesis (typically narrative and conceptual) and analysis (seeking to identify conceptual contributions/novel theory) such that our review has elements of such non-systematic review types as critical, narrative, mapping, mixed methods, scoping, state-of-the-art, and overlapping (Jansen, 2017). Initially, the search was narrower in scope, and included keywords such as: 'SME', 'internationalization', 'effectuation', 'improvisation', and 'bricolage'. However, as the study progressed and newer concepts emerged, the key search terms were expanded to include: 'sense-making', 'decision', 'decision making', 'foreign market entry', 'method', and 'entrepreneurial'. Articles were chosen for review based on their level of contribution to the growing field of literature surrounding SME internationalization. In particular, emphasis was placed on studies that highlighted a shift away from "traditional' to "nontraditional" internationalization models. Given the huge number of 'hits' when using the various search terms and in focussing on contribution, only those articles that are categorized as being either A*, A, or B on the Australian Business Deans Council Journal Quality list were retained. The exception being several articles appearing in the Journal of International Entrepreneurship, which has no ABDC rating, but which we argue contained articles making significant contributions. Books and theses articles were also included.

In order to understand the development of nontraditional theories of SME internationalization, it is crucial to examine the literature that preceded these theories. This literature review begins by exploring the larger concept of internationalization, noting in particular the importance of stage models of internationalization in the field. This section explores why these models are not able to accurately capture the process of SME internationalization, suggesting that SMEs face an inherently different environment than that of larger firms typically analysed in stage model studies of internationalization. Instead, links are drawn between SMEs and entrepreneurs as these two groups often face far more similar conditions, challenges, and environments.
Recent years have witnessed an exponential increase in the literature surrounding SMEs. Due to an increasingly globalized world, such small firms, once confined by national borders, were given the opportunity to access larger international markets. Prior to 1980, studies regarding the internationalization of SMEs were scant, though it was acknowledged early on that, while they are comparatively small, many firms tend to begin operating internationally (Johanson \& Wiedersheim-Paul, 1975). Decades later, Coviello and McAuley (1999) noted once again that internationalization literature was focused primarily on multinational firms, despite the existence of international SMEs. Between the 1980s and the 2000s, the examination of internationalization as a concept was still evolving. Over the course of two decades, several models emerged to explain the process of firms' internationalization, most focusing on key 'steps' for successful entry into the foreign market (Miller, 1993; Yip, Gómez $\&$ Monti, 2000). However, two schools of thought dominated much of the literature: The Uppsala Model (Johanson \& Vahlne, 1977) and the Innovation Models (Bilkey \& Tesar, 1977). Both models approach internationalization as an incremental process that occurs in stages. The Uppsala model is focused on learning through internationalization (Forsgren, 2002) whereas the Innovation models are concerned with internationalization as a form of innovation (Andersen, 1993). In a detailed analysis of the two models, Andersen (1993), explains that the Uppsala model has a much higher generalizability than the innovation models. This is largely due to the fact that the Uppsala model presents a more abstract and open theory towards the process of internationalization that is less precise in terms of the conditions in which it applies (Andersen, 1993). Thus, it is easier to apply the Uppsala model in a variety of contexts. As such, it is the primary model to which we refer when comparing traditional models with newly-developed ones.

\section{The Uppsala Model}

Introduced in 1977, the Uppsala model was developed to provide a dynamic model to explain the internationalization process of firms. The model itself is grounded in the "gradual acquisition, integration, and use of knowledge about foreign markets and operations, and on its successively increasing commitment to foreign markets" (Johanson \& Vahlne, 1977, p. 23). Essentially, the model explains firms' internationalization as a gradual process, whereby firms take small steps towards increasing their resource commitment to foreign markets while they gain more knowledge about those markets (Johanson \& Vahlne, 1977). A fundamental assumption to the model is 
that limited knowledge presents a large obstacle for firms (Johanson \& Vahlne, 1977). Johanson and Vahlne (1977) suggest that this obstacle is overcome through experience operating in foreign markets, given that experience provides knowledge. They further suggest that knowledge of changes within the firm and its environment can reveal unseen problems and opportunities, which thereby enables the firm to make important decisions (Johanson \& Vahlne, 1977). The Uppsala model suggests that the output of each decision made contributes to the input of subsequent decisions, and thus firms follow an incremental process of decision-making to further their international operations (Johanson \& Vahlne, 1977). In 2003, the Uppsala model was expanded upon to account for the importance of relationships and networks in the process of internationalization. Johanson and Vahlne (2003) indicate that relationships, mutually built over time in the interest of both parties, enable firms to enter new markets and develop new relationships in those markets. These relationships can result from ad hoc events or from planned partnerships, and each relationship must be considered in the context of the firm's wider network in order to be properly understood (Johanson \& Vahlne, 2006). Furthermore, the Uppsala model suggests that within this framework, firms focus on foreign markets where psychic distance (i.e. the difficulty to understand the foreign environment) is low, and therefore the liability of outsidership or the risk associated with being an outsider is low (Johanson \& Vahlne, 2009). According to the model, firms begin by exporting (through agents) to culturally similar and nearby countries, and only after gaining sufficient knowledge consider establishing subsidiaries in the foreign markets (Johanson \& Vahlne, 1977; 2009).

The simplicity and generalizability of the Uppsala model have made it largely accepted in the literature, and several studies support the applicability of the model (Clark, Pugh \& Mallory, 1997; Davidson, 1980; Erramilli, 1991; Fina \& Rugman, 1996). However, the model has received some criticism. Bell (1995) contested that the relevance of 'stage' theories in general was questionable in a globalizing world. Autio (2005) also noted that a shift in global environmental conditions, such as lower international travel costs and faster flow of information, made it difficult to apply the Uppsala model after the 1970s. Additionally, as the Uppsala model allows for a high level of generalizability, it cannot account for many particularities that internationalizing firms face (Andersen, 1993; Forsgren, 2002). Most notably, Oviatt and McDougall (2005) suggested that the Uppsala model is not focused on examining entrepreneurial processes, and is therefore difficult to apply in the case of SMEs. Though the model has been applied towards the internationalization of SMEs in certain cases, the model still faces limitations within this context. In their revision of the model, Johanson and Vahlne (2003) expanded their theory to include the impact of networks and relationships; however, the model is still unable to explain the internationalization of SMEs that occurs rapidly, with high risk, or in fluid sequence rather than in stages. Although the Uppsala model continues to be refined by its creators, the Vahlne and Johanson (2017) and Vahlne and Johanson (2020) iterations focus on multinational business enterprises (MBEs) and specifically, the general psychological characteristics of managers therein, which makes them therefore, somewhat beyond the scope of the present paper's focus on SMEs.

More recent reference to the Uppsala model has revealed that as a theorization of firm internationalization, it does lend itself well to microfoundational approaches that look at the role of managerial cognition and the decision-making processes related to the details and dynamics of location, type, mode and timing of foreign market entry (Niittymies \& Pajunen (2020). However, as Paul and Rosado-Serrano (2019) note, there still needs to be more work done in the area of integrating gradual internationalization theory (e.g., the Uppsala model) with born-gobal/international new venture theory, and especially integrating them with attention to the role that knowledge plays in both (Gulanowski, Papadopoulos \& Plante, 2018). Thus, this paper aims to focus the discussion on characteristics of SME internationalization that are not adequately captured by the Uppsala model. We begin this discussion with an overview of the factors that differentiate the SME context from that of larger firms.

\section{Small to Medium-Sized Enterprises (SMEs)}

SMEs face a set of challenges that are fundamentally different from those faced by multinationals. Most often, SMEs lack the financial and human resources that larger firms rely on to enter foreign markets (Knight and Cavusgil, 2004). Many SMEs are also relatively young and lack the experience that multinationals have, given that they have had the time to cultivate (Etemad \& Wright, 2003; Lu \& Beamish, 2001). However, despite these constraints, many SMEs are able to establish themselves in international markets (Weerawardena, Mort, Liesch \& Knight, 2007). It has also been found that SMEs, unlike multinational enterprises, have a tendency to "seek risk rather than avoid it" (Ketkar \& Acs, 2013, p. 205). Moreover, the emergence of born-global firms and international new ventures (INVs) has created a new set of SMEs that are committed to international markets from their inception, thereby bypassing several 'stages' outlined in the more 
established models of internationalization (Coviello, 2015; Knight \& Cavusgil, 2004; Oviatt \& McDougall, 1994). Many SMEs follow a "non-systematic" approach to internationalization that is not necessarily indicative of an an incremental decision process (Papadopoulos \& Martín Martín, 2011). Thus, several studies have concluded that stage-based theories of internationalization, such as the Uppsala model, are not always appropriate for understanding the behaviour and processes adopted by SMEs (Bell, 1995; Madsen \& Servais, 1997; McDougall, Shane \& Oviatt, 1994; Oviatt \& McDougall, 2005).

Consequently, the question arises, on what basis can we develop theories that explain the internationalization of SMEs? We aim to address this question by drawing links between entrepreneurship and SMEs. Examining the entrepreneurship literature reveals that several similarities can be identified between entrepreneurs and SMEs, such as management styles, resource constraints, and levels of uncertainty. Thus, entrepreneurship literature holds significant value for SME literature. The overlap identified in the following section delineates that both entrepreneurs and SMEs share basic commonalities that enables researchers to apply entrepreneurship theories to SMEs in the context of internationalization.

\section{SMEs and Entrepreneurship}

Earlier research on SME internationalization mainly drew upon established MNE theory where questions about MNE theory utility was limited, but some links were drawn between entrepreneurship and SMEs. Etemad and Wright (2003) suggest that small firms can act entrepreneurially and are increasingly able to take advantage of foreign opportunities that were once reserved for multinationals. The process of conducting transactions abroad has, in itself, also been viewed as inherently entrepreneurial (McNaughton, 2003). This idea can also be seen in the work of Hashai and Almor (2004), who outline that firms that are globally-oriented from inception typically follow an entrepreneurial management structure. Other SME literature highlights similar findings. Javalgi, Todd, and Granot (2011, p. 546) note that even SMEs in developing economies, such as India, often act as "an extension of the management's orientation with regard to internationalization and entrepreneurial orientation". It has also been noted that this entrepreneurial orientation coupled with the previous overseas experience can increase the propensity for an SME to internationalize (Alayo, Maseda, Iturralde \& Arzubiaga, 2019; Cabrol \& Nlemvo, 2009; Ibeh \& Kasem, 2011). However, this propensity does not reduce the high levels of ambiguity and uncertainty that both entrepreneurs and SMEs face
(Hilmersson \& Jansson, 2012). Thus, there is clear overlap between entrepreneurs and SMEs, which has allowed researchers to extend certain concepts from one domain to the other. Not only can entrepreneurial ideas be applied to SMEs, but SMEs themselves can be viewed as inherently entrepreneurial based on their decision-making nature, their organizational structure, and the uncertainty they face.

The next section of the paper analyzes entrepreneurial approaches that were developed within a domestic context, such as effectuation and bricolage. These approaches, though not originally intended for an international analysis, have been applied to SME internationalization precisely as a result of the similarities between entrepreneurs and SMEs outlined above. Additionally, effectuation and bricolage introduce several ideas that have enabled the development of newer approaches to internationalization of SMEs, such as resource scavenging, which is explored in a later section of the paper.

\section{Four Key Nontraditional Approaches}

\section{Effectuation}

Sarasvathy (2001) introduced effectuation as a new approach to understanding entrepreneurial behaviour. Based on effectuation logic, this approach focuses on 'sense-making', and is primarily used when the future is unpredictable, and goals are undefined. Effectuation logic is defined as the opposite of causal logic, which relies on assuming a predictable future and predefined goals. Causal logic is a prominent pattern of thinking in business school textbooks (Kotler, 2003). The same logic is also inherent in the stage models of internationalization (Johanson \& Vahlne, 1977). Sarasvathy (2001) notes that although the two are strikingly different, entrepreneurs can adopt both forms of thinking - typically leaning towards effectuation in earlier stages and causation in later ones. She suggests that effectuation holds great value for new entrepreneurs as it takes into account the resource limitations that they face. The five principles of the effectuation model, as defined by Sarasvathy (2001), are briefly explained below:

\section{Using Existing Means}

Entrepreneurs acting effectually recognize their three primary means: (1) Personal Traits, (2) Expertise and Experience, and (3) Networks, both social and professional. Effectuation logic indicates that entrepreneurs configure and reconfigure their means in order to explore the many possible ends that can be achieved. Emphasis is placed on creativity and openness. 


\section{Focusing on Affordable Losses}

Effectuation theory suggests that entrepreneurs are open to losses that are 'acceptable', to the extent that they create potential for future gains. In other words, entrepreneurs working effectually avoid expending their limited resources on risk aversion, but rather accept a certain level of risk knowing that this present loss will lead to future opportunity.

\section{Leveraging Contingencies}

Entrepreneurship is rich in unpredictability. Therefore, successful entrepreneurs are the ones who can welcome changes; i.e. contingencies, to their resources or environment. Effectual entrepreneurs work to accept and adapt to these new serendipitous changes and events that occur, whether they are positive or negative.

\section{Forming Strategic Partnerships}

Sarasvathy (2001) explains that entrepreneurs facing resource constraints can find success through partnerships. Entrepreneurs are often unable to complete competitive analyses, where the focus is on identifying and dealing with current and potential competitors, as a result of insufficient information and knowledge. Instead, entrepreneurs find greater success in building a strong network that allows them to create the potential for future opportunity, as new partnerships can result in resources, knowledge, and opportunities that were once unavailable.

\section{Controlling Instead of Predicting}

The final principle, which lies at the heart of effectuation, explains that entrepreneurs do not need to predict the future to be successful. Instead, success can be achieved by focusing on utilizing current resources as efficiently as possible in an effort to discover what possibilities are available in the unpredictable environment (Sarasvathy, 2001).

Since the introduction of effectuation in 2001, the literature surrounding the topic has increased greatly. Not only has Sarasvathy's (2001) approach been applied to entrepreneurship, but it has also established a base in the SME internationalization literature (Johanson \& Vahlne, 2009; Meyer \& Skak, 2002; Spence \& Crick, 2006). Several studies are previously outlined that present empirical evidence which suggest that SMEs, acting entrepreneurially, follow effectuation logic to aid them in navigating through the process of internationalization.

\section{Empirical Evidence}

One of the first indications of the relevance of effectuation logic to SME internationalization was published shortly after Sarasvathy's (2001) study. Meyer and Skak (2002) discovered that the concept of serendipity played an important role in the international entry of SMEs. Firms that were more flexible and sensitive towards potential opportunities, or serendipitous events, that arose unexpectedly were more successful in internationalizing (Meyer \& Skak, 2002). Though the authors did not explicitly make the connection between their study and Sarasvathy's (2001) findings, the behaviour they emphasized is clearly outlined in effectuation theory, under the principle of leveraging contingencies. Indeed, both entrepreneurs and internationalizing SMEs benefit from maintaining an openness and awareness of chance events. This idea, though not explicitly connected to effectuation, was supported by Spence and Crick (2006) in their empirical analysis of the internationalization processes of several high-tech SMEs. The authors discovered that many firms relied on serendipity within the framework of effectuation theory to guide their internationalization, focusing on "intuition rather than proceeding via a systematic planning process" (Spence \& Crick, 2006, p. 537). Moreover, Johanson and Vahlne (2009) also agree that effectuation is highly applicable to the internationalization context.

For several years, studies surrounding effectuation were limited to the entrepreneurial context and not extended into the area of internationalization. However, recognizing internationalization as an entrepreneurial process, through the analysis of an entrepreneurial firm's internationalization efforts, Schweizer, Vahlne and Johanson (2010) suggested adjustments to their internationalization process model that acknowledge effectual decision-making. Similarly, Harms and Schiele (2012) concluded that experienced entrepreneurs tend to apply effectual logic in their international venture creation, while other researchers suggested that effectuation could permit greater insight into the idiosyncrasies of SME internationalization (Evers \& O'Gorman, 2011; Kalinic \& Forza, 2012). Effectuation provides a clear cognitive process that allows SMEs to overcome resource obstacles that would otherwise be considered unsatisfactory for internationalization where the willingness to act in the face of uncertainty is often linked to the effect that social networks have on perceptions of international opportunities (Nowiński \& Rialp, 2016). This is perhaps explained by the fact that firms grounded in effectuation 
logic focus on creating opportunities rather than discovering them (Gabrielsson \& Gabrielsson, 2013). Opportunity creation can reveal new possibilities that would have otherwise gone unnoticed. This proactive attitude, reflective of effectuation, has been considered a key distinguishing factor for INVs and born-global firms (Evers \& O'Gorman, 2011). Gabrielsson and Gabrielsson (2013, p. 1371), in their study of high-technology business to business INVs in small open economies found that effectuation logic can allow these firms to compete despite the "liabilities of smallness, newness, and foreigness" that they face. Furthermore, studies have indicated that SMEs following effectual logic can overcome the liability of outsidership found in the Uppsala model as this approach enables them to build their network and knowledge during the process of internationalization (Kalinic, Sarasvathy \& Forza, 2014). Sarasvathy, Kumar, York \& Bhagavatula, (2014) go so far as to argue that an effectual approach in the context of international entrepreneurship can resolve four central knowledge gaps associated with: 1) generalizability; e.g., social ventures and innovative organizational forms; 2) method; e.g., counterfactual analyses; 3) unit of analysis; e.g., the intersubjective; and 4) scope, e.g., transnational and post-national ventures.

Recently, studies suggest that employing effectuation plays a significant role in firms' Foreign Market Selection (FMS) and Foreign Market Entry (FME). Galkina and Chetty (2015) provide evidence of firms creating international opportunities for FMS by focusing on forming strategic partnerships, rather than developing a comprehensive and time-consuming analysis of foreign markets. Firms were able to identify and enter potential markets as a result of their partnerships (Galkina \& Chetty, 2015). Chandra, Styles, and Wilkinson (2009) found that, consistent with Sarasvathy's (2001) findings, SMEs in fact benefit from partnerships over a competitive view towards foreign firms. However, some studies suggest that, although firms were initially more inclined to use effectuation for both FMS and FME, the actual processes involved a blend of both causal and effectual logic (Chetty, Ojala \& Leppäaho, 2015). Similarly, SME internationalization literature explains that firms can implement both causation and effectuation logic while internationalizing. Most studies suggest that young firms, including born-global or INVs, rely on effectuation at first, but eventually shift towards a more causal approach when constraints and unpredictability are less apparent (Crick \& Crick, 2014; Gabrielsson \& Gabrielsson, 2013; Nummela, Saarenketo, Jokela \& Loane 2014). Bridging the international entrepreneurship and effectuation literatures, Karami, Wooliscroft and McNeill (2019) provide a detailed review of the role of effectuation in SME internationalization; noting that while effectuation has evolved significantly in entrepreneurship, it still has much to offer in the study (and practice) of SME internationalization.

Evidently, there is strong support within the literature for the application of effectuation to the process of SME internationalization. The studies above can be viewed as the beginning of acknowledging nontraditional approaches towards the entry of SMEs into the foreign market. Indeed, at present, effectuation is the dominant approach found in the literature; however, several other approaches exist that deviate from traditional thinking. Though they are less developed than effectuation in the context of SME internationalization, they have been proven to be relevant and hold great potential for future research. One approach that, like effectuation, borrows from the field of entrepreneurship is bricolage. Unlike effectuation, however, bricolage is focused on the use of resources and is concerned predominantly with the resource constraints faced by entrepreneurs. As outlined in the following section, the idea of overcoming resource constraints through bricolage can apply to both entrepreneurship and SME internationalization.

\section{Bricolage}

Though Claude Levi-Strauss first introduced bricolage in 1966, it was not applied to the field of entrepreneurship until after the turn of the century. Bricolage was loosely defined at the time, essentially focusing on the idea of 'making do with what is at hand' (Lévi-Strauss, 1966). However, many years later, Baker and Nelson (2005) developed a concise definition of bricolage within the framework of entrepreneurship. Bricolage can be characterized as an 'improvisational' approach to resources that enables entrepreneurs to achieve success by reconfiguring their existing means (Baker \& Nelson, 2005). The three basic elements of their definition are briefly outlined below.

\section{Making Do}

At its core, bricolage occurs when entrepreneurs manage to utilize their available resources efficiently. However, bricolage also involves a stronger emphasis on active engagement with resources rather than planning. Additionally, entrepreneurial bricolage is often characterized by a willing disregard for the common limitations associated with entrepreneurs' resources, which enables opportunity creation. 


\section{Combination of Resources for New Purposes}

Bricolage is focused on maximizing the potential of available resources. As a result, entrepreneurs adopting bricolage often focus on re-using and combining their existing means. This has led to new, innovative, and sometimes serendipitous discoveries that would not have occurred if bricolage was not a prominent entrepreneurial approach.

\section{The Resources at Hand}

The resources that an entrepreneur has at their disposal can be both tangible and intangible. For entrepreneurs following the bricolage approach, materials such as equipment and manpower are just as important as knowledge and experience. These resources also include the means that entrepreneurs can obtain for free or for a minimal cost.

Despite the links indicating that bricolage could be relevant in the internationalization of SMEs, little research exists that explicitly connects the two fields. Indeed, studies exist where bricolage is present, but the term itself is not employed by researchers. For example, Chandra et al. (2009) noted that SMEs found greater success internationalizing through the combination and matching of pre-existing means, such as resources and skills. Though the authors do not express the connection, the process they describe is a key principle in bricolage (Baker \& Nelson, 2005) in that they clearly describe the process of recombining resources with knowledge to adapt to new situations. Few empirical studies exist that have directly connected bricolage to SME internationalization. Desa (2011) documented bricolage in the processes of international social ventures, noting in particular that bricolage could enable the creation of a usable product from scarce resources while simultaneously building organizational resilience. In the same year, Evers and O'Gorman (2011) noted that 'network bricolage' can facilitate the SME internationalization process. Network bricolage refers to the opportunity that arises when firms unexpectedly (or serendipitously) receive information and resources through changes in their network (Baker, Miner \& Eesley, 2003).

\section{Resource Scavenging}

Though the explicit links between bricolage and SME internationalization are not extensively documented in the literature, bricolage has had an impact on SME internationalization research. Resource scavenging is a relatively new approach towards the SME internationalization process, identified as being similar to bricolage in certain aspects, but founded on different characteris- tics (Hewerdine, Rumyantseva \& Welch, 2014). Both bricolage and resource scavenging focus on SMEs that face constrained resources in largely unpredictable environments, where resources are crucial for future development (Hewerdine et al., 2014). Resource scavenging, however, is concerned primarily with internationalizing for the purpose of obtaining resources - which is a key difference between the two approaches (Hewerdine et al., 2014). Furthermore, Hewerdine et al. (2014) highlight that resource scavenging is based on developing relationships to obtain resources through a non-systematic and improvisational process of social networking. Thus, the authors have branched away from bricolage to introduce a new internationalization process that deviates from the 'traditional' stage model approach. Resource scavenging, like both effectuation and bricolage, undoubtedly holds great potential for future development of SME internationalization research.

The three strategies discussed in sections Effectuation, Bricolage, and Resource Scavenging are all rooted in similar concepts, one of which is the importance of social networks and partnerships for SMEs entering foreign markets. Additionally, the importance of these networks has been highlighted by Johanson and Vahlne (2003) as pertinent to the internationalization process. Therefore, it is unsurprising that the concept of social capital appears within the SME internationalization literature.

\section{Social Capital}

Social Capital was first introduced by Hanifan (1916) who suggested that strong social relationships were crucial for the improvement of a community. This definition, though broad, has evolved over time and been applied to many fields of study such as economics, social psychology, and entrepreneurship. Typically, social capital is defined as the sum of resources that can potentially be derived or obtained from one's social network (Adler \& Kwon, 2002; Nahapiet \& Ghoshal, 1998).

Social capital has also been examined as an important factor within entrepreneurship (Aldrich \& Zimmer, 1986; Elfring \& Hulsink, 2003). The entrepreneurship literature emphasizes the role of social networks as sources of both opportunity and resources (Chandra et al., 2009). This view is consistent with effectuation, bricolage, and resource scavenging - as all three highlight the potential opportunity that can arise through resources, both tangible and intangible, obtained from networks (Baker \& Nelson, 2005; Hewerdine et al., 2014; Sarasvathy, 2001). However, it is important to note that the role of social capital can occur in both traditional models of internationalization and nontradi- 
tional models (Lindstrand, Melén \& Nordman, 2011). Our research is concerned with the latter.

There are a handful of studies that highlight the role of social capital in the context of SME internationalization. Generally, social ties have been found to play a key role in the discovery of international opportunities (Chandra et al., 2009; Johanson \& Vahlne, 2006). Similarly, in a study focused on supplier-customer relationships, Bradley et al. (2006) noted that the stronger the bonds between SMEs, the greater the potential for access to new foreign customers and greater overall commitment to foreign markets. Social capital has also been found to trigger FME in SMEs, as opportunities in foreign markets become apparent through social connections (Agndal, Chetty \& Wilson, 2008; Ciravegna, Lopez \& Kundu, 2014; Coviello \& Munro, 1997; Zhao \& Hsu, 2007). Even in developing markets, SME internationalization is influenced by opportunites that arise through social connections or opportunities that are pursued directly through relationships (Ibeh \& Kasem, 2011). These opportunities have been termed 'serendipitous', as they often appear without warning from partners with whom firms have weak or indirect relationships (Agndal et al., 2008; Kontinen \& Ojala, 2011). One study of Czech SMEs even suggests that weak social relationships are more beneficial than strong ones because they provide firms with information that facilitates international opportunity identification (Musteen, Francis \& Datta, 2010). Additionally, the role of social capital has also been noted to reduce the uncertainty and level of risk involved in internationalization (Musteen, Datta \& Butts, 2013). Notably, the serendipitous opportunities that arise from unconventional social ties indicate a divergence from a stage-model approach to internationalization. Instead, the role of social capital outlined above is indicative of an approach where contingencies are welcome, and partnerships are valued for their indirect potential to promote internationalization.

\section{Linking Old Approaches to New Approaches}

The four approaches above comprise a large portion of the research surrounding nontraditional stage model approaches to SME internationalization. This is largely because there are several ideas that are common to each of the above approaches. Evidently, there are clear similarities between effectuation and bricolage. Bricolage outlines that entrepreneurs who clearly disregard the commonly defined resource limitations are often able to do much more with their resources. This is likely due to the fact that perceived resource limitations create perceived barriers that dissuade SMEs from entering international markets (Xie \& Suh, 2014). Additionally, Baker and Nelson (2005) stress the importance of combining resources and maintaining and open outlook to include as many available resources as possible, including soft skills and previous experience. These three principles are identical to the principle of 'Using Existing Means' outlined by Sarasvathy (2001). Sarasvathy's definition essentially synthesizes Baker and Nelson's three principles into one group. This idea has also been supported in the literature (Fisher, 2012). Additionally, bricolage, resource scavenging, and social capital all emphasize the importance of social networks (Baker \& Nelson, 2005; Chandra et al., 2009; Hewerdine et al., 2014). As evidenced above, small firms often find knowledge, resources, and even opportunities through their social networks that were once unattainable due to the constraints they faced. This is also outlined as a key principle of effectuation, termed 'Forming Strategic Partnerships' (Sarasvathy, 2001). More recently, Sedziniauskiene, Sekliuckiene and Zichella (2019) provide a detailed review of the role that networks play in entrepreneurial internationalization; noting that there is still much to be learned about their impact in the early and fast growth of new international ventures in global markets, while Kujala and Törnroos (2018) use network and effectuation approaches to explain SME internationalization from emerging to affluent markets. Coviello (2015) also highlights the importance of better understanding those key actors(s) that are critical and central to the firm's internationalization behaviour.

Though each approach to internationalization of SMEs presents a unique perspective towards the process, Sarasvathy's (2001) effectuation theory arguably provides the most cohesive approach that partially or wholly discusses certain aspects of the other three approaches. We can see that bricolage is summarized within the 'Using Existing Means' principle of effectuation, while aspects of resource scavenging can be found within the 'Forming Strategic Partnerships' principle. The literature surrounding social capital can also be found in this principle, but also within the 'Leveraging Contingencies' aspect of effectuation. Therefore, though each theory independently holds value for the field of SME internationalization, effectuation seems to be the common denominator that links these approaches that have contributed to forming the basis of SME internationalization literature.

However, new approaches have recently emerged that present new perspectives to the field. These approaches, namely muddling-through and dynamic experimental internationalizing, are distinct in their analysis of the processes followed by firms when entering foreign markets. Muddling-through, like effectuation and bricolage, 
originates from an entirely different field of study. The approach was developed within the context of political science, but its applications to SME internationalization are quite pertinent. Comparably, dynamic experimental internationalization is a very recent approach that, unlike the others, was developed entirely within the framework of SME internationalization.

\section{Muddling-Through}

The idea of muddling-through originated from the research field of public administration. In 1959, Charles E. Lindblom introduced the concept of Muddling-through as a process that explains how policy makers make decisions. Lindblom (1959) suggested that the rational means-end approach to decision-making, characterized by predefined goals and decisions aimed at fulfilling those goals, was inaccurate in capturing the reality faced by policy makers. Instead, he noted that decisions were made in contexts where goals could not be clearly defined and so policy makers resorted to 'muddling-through' the limited information available to reach an undefined end (Lindblom, 1959). Johnston, Low, and Wilson (2012, p. 717) explain that in adopting the muddling-through approach, the "focus is on moving away from the present situation, not particularly toward something". This notion of goal ambiguity is evident in a study of SMEs in India, where turbulent and uncertain situations made muddling-through the only plausible choice for internationalization (Javalgi, Todd, Johnston \& Granot, 2012). Javalgi et al. (2012) found that firms worked without clear goals to analyze their choices, make decisions, and then re-analyze their new situation to make successive decisions - creating a 'cycle' of decision-making for entering foreign markets. Furthermore, a case study of internationalizing SMEs following the muddling-through process, revealed that firms made decisions intuitively and spontaneously based on their analysis of the given circumstances (Schweizer, 2012). These studies provide a clear indication that Lindblom's method to decision making holds value for the internationalization of SMEs.

It is important to note that, although the muddling-through approach to internationalization involves making sequential/successive decisions, it is inherently non-causal. The approach focuses on making decisions in the present, with no defined idea of what the future looks like (Lindblom, 1959). This is quite similar to the definition provided by Sarasvathy (2001) for the process of effectuation logic. In fact, Sarasvathy (2001) explains that the Lindblom's muddling-through played a role in the development of effectuation theory. Lindblom's theory of muddling-through focuses on policy makers making decisions in which the means and the ends are not separated (Lindblom, 1959). Sarasvathy (2001) notes that this logic is reflective of an effectual approach and thus linked to her concept of effectuation. As a result, all the research surrounding muddling-through in the SME internationalization context makes mention of effectuation. Notably, Javalgi et al. (2012) explicitly equate muddling-through and effectuation as two identical approaches in different domains; Lindblom's in political science and Sarasvathy's in entrepreneurship. Though the two are used in different contexts, Lindblom's for policy making and Sarasvathy's for entrepreneurial decision making, both follow an inherently identical logic (Javalgi et al., 2012). Thus, the application of muddling-through to SME internationalization is rooted in the concept of effectuation.

\section{Dynamic Experimental Internationalization}

Finally, we examine Dynamic Experimental Internationalization as another nontraditional approach to SME internalization. This approach focuses on SMEs entering foreign markets from within a transitional economy. Although other researchers have studied SME internationalization within the context of transitional economies (Mainela \& Puhakka, 2009; Musteen et al., 2013; Thai \& Chong, 2013), Zhao and Hsu (2007), they present an independent approach to the process. Dynamic Experimental Internationalization theory notes that SMEs in transitional economies face rapidly changing environments, limited experience, and limited information with which to make decisions (Huang \& Brown 1999; Thai \& Chong, 2013). As a result, firms typically adopt a process that is experimental, intuitive, and spontaneous which better allows them to take advantage of opportunities that emerge through the process itself (Thai \& Chong, 2013). Thai and Chong (2013) acknowledge that their process resembles effectuation to an extent, but clarify that firms employing this approach are often working toward a defined goal. Therefore, dynamic experimental process creates an interesting approach to SME internationalization. Although, on the one hand, goals are defined, as they would be under rational/causal logic and stage-models of internationalization, on the other hand, the pathway to achieve those goals is unclear and unplanned. Hence, we find that SMEs operating and internationalizing from within a transitional economy benefit from end goals but not from strategic planning, with respect to the process itself.

\section{Discussion}

As briefly mentioned throughout this paper, there are clear commonalities that exist between the six SME 
internationalization approaches that we have identified. In an effort to consolidate and present a comprehensive understanding of the axes upon which these approaches can be combined and employed, we examine these commonalities below.

One of the most prevalent ideas found in the literature is the importance of serendipity and serendipitous events. For internationalizing SMEs, serendipitous events can occur at any time through a variety of ways. In the view of Sarasvathy (2001), serendipity is the result of unanticipated environmental changes. Some authors have expanded on this to define more specific sources of serendipity. For example, while Baker and Nelson (2005) explain that serendipitous events can occur through the combination and reorganization of existing resources, Agndal and Chetty (2007) suggest that they can occur when social relationships provide firms with knowledge and information. Regardless of their source, it is clear that serendipity and serendipitous events are crucial given that they can allow firms to both identify and create opportunities for FMS and FME. Thus, internationalizing SMEs benefit greatly from maintaining an awareness and openness towards unplanned changes to their conditions.

Additionally, previous research is consistent with respect to the importance of social networks for SMEs engaging in foreign markets. As noted earlier, social relationships can result in serendipitous events (Agndal \& Chetty, 2007); however, their importance extends beyond the creation of potential opportunities. Social networks can also provide resources and knowledge that were once unavailable (Baker et al., 2003; Sarasvathy, 2001). In resource scavenging, they are key factors that enable the internationalization of firms (Hewerdine et al., 2014). They have also been found to reduce the perceived risk and uncertainty associated with entering foreign markets (Musteen et al., 2013). Social networks serve many functions that can benefit firms throughout the internationalization process. As the literature explains, they are key to the successful internationalization of SMEs.

A third and final commonality that emerges in the literature studied, is the underlying role of improvisation. Improvisation is discussed as an important factor within bricolage, as it enables entrepreneurs and SMEs alike to 'make do' with their existing means through unplanned processes of reconfiguring and recombining those means (Baker \& Nelson, 2005). Though not explicitly discussed in other studies, the concept of improvisation can be found as an underlying factor in much of the literature outlined above. In the field of management, improvisational tactics are ones that involve a high degree of convergence between design and execution (Moorman \& Miner, 1998). In other words, improvisation occurs when little time elapses between decision-making and acting on those decisions. Therefore, improvisation can be found in all the internationalization approaches presented in this paper, both those that emphasize serendipity (i.e. effectuation, bricolage, and social capital) and those that emphasize experimental processes (i.e. resource scavenging, muddling through, and dynamic experimental internationalization).

The various non-tradtional theoretical approaches to SME internationalization outlined in this paper represent a variety of perspectives and ideas; however, they do share some similarities. The commonalities outlined above denote that serendipity, social networks, and improvisations are key characteristics shared by the approaches. This highlights that these approaches are not mutually exclusive and can be implemented in conjunction with one another. In fact, this notion is already supported in the literature. Nowińksi and Rialp (2016) found evidence of both bricolage and effectuation in the internationalization processes of SMEs, while Evers and O'Gorman (2011) determined that effectuation, bricolage, and improvisation can collectively explain how internationalization processes begin in some SMEs. It is important to note that effectuation and principles rooted within effectuation can be linked to all other nontraditional approaches of internationalization. This is likely because effectuation provides a holistic framework that takes into consideration several aspects of the internationalization process. However, effectuation is not fully applicable in certain circumstances (Lertboonsupa, 2016; Prashantham, Kumar, Bhagavatula \& Sarasvathy, 2019; Thai \& Chong, 2013 for discussions regarding contingencies associated with effectual versus causal approaches), therefore a combination of approaches can be beneficial to SMEs.

\section{Conclusions and Implications}

In conclusion, it is clear that the internationalization of SMEs is a continuously growing field of study that has evolved rapidly over the last three decades. This review of the literature recognizes that initial research on the topic was adapted from traditional stage models of internationalization (e.g., the Uppsala model) developed in the context of multinational organizations. Unfortunately, as many studies have found, the stark difference in circumstances between the internationalization of MNEs and SMEs has made it difficult to develop a strong understanding of SME internationalization through these models. As such, the understanding of SME internationalization has greatly benefited from research on entrepreneurship. And, since entrepreneurs face similar resource 
constraints and unpredictable environments like SMEs, approaches examined in the entrepreneurship literature were found to be far more applicable to SMEs.

Two key entrepreneurial approaches, effectuation and bricolage, have been documented in the SME internationalization process. These approaches have provided researchers a much more accurate method of understanding the spontaneous, unplanned processes that SMEs follow when engaging with foreign markets. There is still much to be done, however. There are perhaps, contingencies in the ability to generalize the role that effectuation plays in SME internationalization. For example, Lertboonsupa (2016) argues that traditional causal thinking influences how firms adapt their products in foreign markets to a higher extent than firms applying effectual thinking, but contrary to the extant literature, effectual logic leads firms to employ riskier, more resource-heavy market entry modes, resulting in enhanced international performance. Relatedly, Prashantham et al. (2019) note that an effectual approach to network-building positively influences initial entry speed and international scope speed, but negatively influences international commitment speed, whereas non-effectual/causal approaches negatively influence initial entry speed and international scope speed, but positively impact international commitment speed.

Moreover, several additional approaches have been developed that deviate from the traditional pattern of thinking that was commonplace before the 2000 s. Resource scavenging, social capital, muddling through, and dynamic experimental internationalization are all approaches that provide new insight into the field. Along with effectuation and bricolage, these four can be viewed as the foundation of nontraditional approaches to SME internationalization.

The findings compiled in this paper provide implications for both academics and professionals. Our comprehensive critical review of literature in the field provides current and future researchers an initial framework upon which they can expand. As this field of research is relatively new, there is significant room for development. This study presents six nontraditional approaches to internationalization that are minimally developed, and thus warrant greater empirical and analytical study - all the while being mindful of the recent findings regarding when and where effectual versus traditional/causal thinking appears to be more appropriate in internationalization. The major limitation of the present paper is the acknowledgement that being a non-systematic literature review, it confers less attention to the rules and rigour associated with systematic reviews. The study also proposes that the convergence of these six approaches, in itself, warrants greater research. In particular, the connections between effectuation and the other nontraditional approaches are still underdeveloped and since these overlapping commonalities are evident, further research is imperative. For example, studying the 'Forming Strategic Partnerships' principle of effectuation by empirically linking it to the literature surrounding social capital may provide greater depth to our understanding of the role of relationships in SME internationalization processes. Additionally, as effectuation theory is still developing within this context, its ties to certain aspects of internationalization (such as the impact of cultural differences, language barriers, and geographic distance) are very limited. Thus, this is an additional key area of potential research that could be targeted by future researchers. Ideally, this study provides an overview of the current state of the nontraditional SME internationalization literature that researchers can consult as an initial source when developing new research studies. Moreover, the implications for professionals are more concrete and visible. Entrepreneurs and SMEs can both obtain valuable information regarding internationalization through this paper. The various approaches outlined above can be explored and adopted by professionals to guide their entry into foreign markets, but once again, being mindful of where product adaptation, entry mode type, and speed and scope of entry are associated with different performance depending on whether employing traditional or non-traditional SME internationalization. Both entrepreneurs and SME management teams could benefit from an approach that emphasizes welcoming and accepting unpredictability and change, as this will enable a stronger ability to adapt to the unpredictable nature of internationalization. Furthermore, these professionals could benefit from maintaining a higher awareness of potential opportunities that can arise from social networks, as these relationships can be extremely advantageous if acknowledged in a timely manner. Similarly, by shifting their perspective to one that is more flexible rather than grounded in concrete goals and step-wise processes, professionals can invest more time in making the most of their existing resources (as suggested by bricolage and effectuation). Overall, on a larger scale, this paper is particularly useful for new professionals entering the field given that this critical review acts as an introduction to the vast realm of SME internationalization.

\section{References}

Adler, P. S., \& Kwon, S.-W. (2002). Social capital: Prospects for a new concept. The Academy of Management Review, 27(1), 17-40. 
Agndal, H., \& Chetty, S. (2007). The impact of relationships on changes in internationalisation strategies of SMEs. European Journal of Marketing, 41 (11/12), 1449-1474.

Agndal, H., Chetty, S., \& Wilson, H. (2008). Social capital dynamics and foreign market entry. International Business Review, 17(6), 663-675.

Alayo, M., Maseda, A., Iturralde, T., \& Arzubiaga, U. (2019). Internationalization and entrepreneurial orientation of family SMEs: The influence of the family character. International Business Review, 28(1), 48-59.

Aldrich, H. E., \& Zimmer, C. (1986). Entrepreneurship through social networks. In D. Sexton \& R. Smilor (Eds.), The Art and Science of Entrepreneurship (pp. 2-23). Cambridge, MA:Ballinger Publishing Company.

Andersen, O. (1993). On the internationalization process of firms: A critical analysis. Journal of International Business Studies, 24(2), 209-231.

Autio, E. (2005). Creative tension: The significance of Ben Oviatt's and Patricia McDougall's article "Toward a theory of international new ventures." Journal of International Business Studies, 36(1), 9-19.

Baker, T., \& Nelson, R. E. (2005). Creating something from nothing: Resource construction through entrepreneurial Bricolage. Administrative Science Quarterly, 50(3), 329-366.

Baker, T., Miner, A. S., \& Eesley, D. T. (2003). Improvising firms: Bricolage, account giving and improvisational competencies in the founding process. Research Policy, 32(2), 255-276.

Bell, J. (1995). The internationalization of small computer software firms. European Journal of Marketing, 29(8), 60-75.

Bilkey, W. J., \& Tesar, G. (1977). The export behavior of smaller-sized Wisconsin manufacturing firms. Journal of International Business Studies, 8(1), 93-98.

Bradley, F., Meyer, R., \& Gao, Y. (2006). Use of supplier-customer relationships by SMEs to enter foreign markets. Industrial Marketing Management, 35(6), 652-665.

Cabrol, M., \& Nlemvo, F. (2009). The internationalisation of French new ventures: The case of the RhoneAlps region. European Management Journal, 27(4), 255-267.

Chandra, Y., Styles, C., \& Wilkinson, I. (2009). The recognition of first time international entrepreneurial opportunities. International Marketing Review, 26(1), 30-61.

Chetty, S., Ojala, A., \& Leppäaho, T. (2015). Effectuation and foreign market entry of entrepreneurial firms. European Journal of Marketing, 49(9/10), 1436-1459.
Ciravegna, L., Lopez, L., \& Kundu, S. (2014). Country of origin and network effects on internationalization: A comparative study of SMEs from an emerging and developed economy. Journal of Business Research, 67(5), 916-923.

Clark, T., Pugh, D. S., \& Mallory, G. (1997). The process of internationalization in the operating firm. International Business Review, 6(6), 605-623.

Costa, E., Soares, A., \& Sousa, J. (2016). Information, knowledge and collaboration management in the internationalisation of SMEs: A systematic literature review. International Journal of Information Management, 36(4), 557-569.

Coviello, N. (2015). Re-thinking research on born globals. Journal of International Business Studies, 46(1), 17-26.

Coviello, N., \& McAuley, A. (1999). Internationalisation and the smaller firm: A review of contemporary empirical research. Management International Review, 39(3), 223-256.

Coviello, N., \& Munro, H. (1997). Network relationships and the internationalisation process of small software firms. International Business Review, 6(4), 361-386.

Crick, D., \& Crick, J. (2014). The internationalization strategies of rapidly internationalizing high-tech UK SMEs. European Business Review, 26(5), 421-448.

Davidson, W. H. (1980). The location of foreign direct investment activity: Country characteristics and experience effects. Journal of International Business Studies, 11(2), 9-22.

Desa, G. (2011). Resource mobilization in international social entrepreneurship: Bricolage as a mechanism of institutional transformation. Entrepreneurship Theory and Practice, 36(4), 727-751.

Elbanna, S., Hsieh, L., \& Child, J. (in press). Contextualizing internationalization decision-making research in SMEs: Towards an integration of existing studies. European Management Review. Available online 28 February 2020.

Elfring, T., \& Hulsink, W. (2003). Networks in entrepreneurship: The case of high-technology firms. Small Business Economics, 21(4), 409-422.

Erramilli, M. K. (1991). The experience factor in foreign market entry behaviour of service firms. Journal of International Business Studies, 22(3), 479-501.

Etemad, H., \& Wright, R. W. (2003). Internationalization of SMEs: Toward a new paradigm. Small Business Economics, 20(1), 1-4.

Evers, N., \& O'Gorman, C. (2011). Improvised internationalization in new ventures: The role of prior knowledge and networks. Entrepreneurship \& Regional Development, 23(7-8), 549-574. 
Fina, E., \& Rugman, A. M. (1996). A test of internalization theory and internationalization theory: The Upjohn Company. Management International Review, 36(3), 199.

Fisher, G. (2012). Effectuation, causation, and bricolage: A behavioral comparison of emerging theories in entrepreneurship research. Entrepreneurship Theory and Practice, 36(5), 1019-1051.

Forsgren, M. (2002). The concept of learning in the Uppsala internationalization process model: A critical review. International Business Review, 11(3), 257-277.

Gabrielsson, P., \& Gabrielsson, M. (2013). A dynamic model of growth phases and survival in international business-to-business new ventures: The moderating effect of decision-making logic. Industrial Marketing Management, 42(8), 1357-1373.

Galkina, T., \& Chetty, S. (2015). Effectuation and networking of internationalizing SMEs. Management International Review, 55(5), 647-676.

Gulanowski, D., Papadopoulos, N., \&. Plante, L. (2018). The role of knowledge in international expansion: Toward an integration of competing models of internationalization. Review of International Business and Strategy, 28(1), 35-60.

Hanifan, L. J. (1916). The rural school community center. The Annals of the American Academy of Political and Social Science, 67(1), 130-138.

Harms, R., \& Schiele, H. (2012). Antecedents and consequences of effectuation and causation in the international new venture creation process. Journal of International Entrepreneurship, 10(1), 95-116.

Hashai, N., \& Almor, T. (2004). Gradually internationalizing 'born global' firms: An oxymoron? International Business Review, 13(4), 465-483.

Hewerdine, L. J., Rumyantseva, M., \& Welch, C. (2014). Resource scavenging. International Marketing Review, 31(3), 237-258.

Hilmersson, M., \& Jansson, H. (2012). Reducing uncertainty in the emerging market entry process: On the relationship among international experiential knowledge, institutional distance, and uncertainty. Journal of International Marketing, 20(4), 96-110.

Hsieh, L., Child, J., Narooz, R., Elbanna, S., Karmowska, J., Marinova S., Puthusserry, P., Tsai, T., \& Zhang, Y. (2019). A multidimensional perspective of SME internationalization speed: The influence of entrepreneurial characteristics. International Business Review, 28(2), 268-283.

Huang, X., \& Brown, A. (1999). An analysis and classification of problems in small business. International Small Business Journal, 18(1), 73-85.
Ibeh, K., \& Kasem, L. (2011). The network perspective and the internationalization of small and medium sized software firms from Syria. Industrial Marketing Management, 40(3), 358-367.

Jansen, S. H. G. (2017). Bias within systematic and non-systematic literature reviews: The case of the Balanced Scorecard. Masters Thesis. University of Twente, Netherlands.

Javalgi, R. (Raj) G., Todd, P. R., \& Granot, E. (2011). The internationalization of Indian SMEs in B-to-B markets. Journal of Business \& Industrial Marketing, 26(7), 542-548.

Javalgi, R. (Raj) G., Todd, P. R., Johnston, W. J., \& Granot, E. (2012). Entrepreneurship, muddling through, and Indian Internet-enabled SMEs. Journal of Business Research, 65(6), 740-744.

Johanson, J., \& Vahlne, J.-E. (1977). The internationalization process of the firm - A model of knowledge development and increasing foreign market commitments. Journal of International Business Studies, $8(1), 23-32$.

Johanson, J., \& Vahlne, J.-E. (2003). Business relationship learning and commitment in the internationalization process. Journal of International Entrepreneurship, 1(1), 83-101.

Johanson, J., \& Vahlne, J.-E. (2006). Commitment and opportunity development in the internationalization process: A note on the Uppsala internationalization process model. Management International Review, 46(2), 165-178.

Johanson, J., \& Vahlne, J.-E. (2009). The Uppsala internationalization process model revisited: From liability of foreignness to liability of outsidership. Journal of International Business Studies, 40(9), 1411-1431.

Johanson, J., \& Wiedersheim-Paul, F. (1975). The internationalization of the firm - Four Swedish cases. Journal of Management Studies, 12(3), 305-323.

Johnston, W., Low, B., \& Wilson, T. L. (2012). Scientific muddling: Decision making through a Lindblomian lens. Journal of Business Research, 65(6), 717-719.

Kalinic, I., \& Forza, C. (2012). Rapid internationalization of traditional SMEs: Between gradualist models and born globals. International Business Review, 21(4), 694-707.

Kalinic, I., Sarasvathy, S. D., \& Forza, C. (2014). 'Expect the unexpected': Implications of effectual logic on the internationalization process. International Business Review, 23(3), 635-647.

Karami, M., Wooliscroft, B., \& McNeill, L. (2019). Effectuation and internationalisation: A review and agenda for future research. Small Business Economics, 1-35. 
Ketkar, S., \& Acs, Z. J. (2013). Where angels fear to tread: Internationalization of emerging country SMEs. Journal of International Entrepreneurship, 11(3), 201-219.

Knight, G., \& Cavusgil, S. T. (2004). Innovation, organizational capabilities, and the born-global firm. Journal of International Business Studies, 35(4), 334-334.

Kontinen, T., \& Ojala, A. (2011). Social capital in relation to the foreign market entry and post-entry operations of family SMEs. Journal of International Entrepreneurship, 9(2), 133-151.

Kotler, P. (2003). Marketing management. Englewood Cliffs, NJ: Prentice Hall.

Kujala, I., \&Törnroos, J-Å. (2018). Internationalizing through networks from emerging to developed markets with a case study from Ghana to the U.S.A. Industrial Marketing Management, 69, 98-109.

Lertboonsupa, T. (2016). The impact of causation and effectuation on internationalisation process: The multi-dimensional analysis. MSc. Thesis, Thammasat University.

Lévi-Strauss, C. (1966). The savage mind. Chicago, IL: University Of Chicago Press.

Li, L., Qian, G., Qian, Z., \& Lu, I. R. (2018). Aspiration, foreignness liability and market potential: How do they relate to small firms' international entrepreneurial orientation? International Marketing Review, 35(6), 1009-1032.

Lindblom, C. E. (1959). The science of 'muddling through'. Public Administration Review, 19(2), 79-88.

Lindstrand, A., Melén, S., \& Nordman, E. R. (2011). Turning social capital into business: A study of the internationalization of biotech SMEs. International Business Review, 20(2), 194-212.

Lu, J. W., \& Beamish, P.W. (2001). The internationalization and performance of SMEs. Strategic Management Journal, 22, 565-586.

Madsen, T. K., \& Servais, P. (1997). The internationalization of born globals: An evolutionary process? International Business Review, 6(6), 561-583.

Mainela, T., \& Puhakka, V. (2009). Organising new business in a turbulent context: Opportunity discovery and effectuation for IJV development in transition markets. Journal of International Entrepreneurship, 7(2), 111-134.

McDougall, P., Shane, S., \& Oviatt, B. M. (1994). Explaining the formation of international new ventures: The limits of theories from international business research. Journal of Business Venturing, 9(6), 469-487.

McNaughton, R. B. (2003). The number of export markets that a firm serves: Process models versus the born-global phenomenon. Journal of International Entrepreneurship, 1(3), 297-311.
Meyer, K., \& Skak, A. (2002). Networks, serendipity and SME entry into Eastern Europe. European Management Journal, 20(2), 179-188.

Miller, M. M. (1993). The 10-Step road map to success in foreign markets. Journal of International Marketing, 1(2), 89-106.

Moorman, C., \& Miner, A. S. (1998). Organizational improvisation and organizational memory. The Academy of Management Review, 23(4), 698-723.

Musteen, M., Datta, D. K., \& Butts, M. M. (2013). Do international networks and foreign market knowledge facilitate SME internationalization? Evidence from the Czech Republic. Entrepreneurship Theory and Practice, 38(4), 749-774.

Musteen, M., Francis, J., \& Datta, D. K. (2010). The influence of international networks on internationalization speed and performance: A study of Czech SMEs. Journal of World Business, 45(3), 197-205.

Nahapiet, J., \& Ghoshal, S. (1998). Social capital, intellectual capital, and the organizational advantage. The Academy of Management Review, 23(2), 242-266.

Niittymies, A., \& Pajunen, K. (2020). Cognitive foundations of firm internationalization: A systematic review and agenda for future research. International Business Review (in press).

Nowiński, W., \& Rialp, A. (2016). The impact of social networks on perceptions of international opportunities. Journal of Small Business Management, 54(2), 445-461.

Nummela, N., Saarenketo, S., Jokela, P., \& Loane, S. (2014). Strategic decision-making of a born global: A comparative study from three small open economies. Management International Review, 54(4), 527-550.

Oviatt, B. M., \& McDougall, P. P. (1994). Toward a theory of international new ventures. Journal of International Business Studies, 25(1), 45-64.

Oviatt, B. M., \& McDougall, P. P. (2005). Defining international entrepreneurship and modeling the speed of internationalization. Entrepreneurship Theory and Practice, 29(5), 537-554.

Papadopoulos, N., \& Martín Martín, O. (2011). International market selection and segmentation: Perspectives and challenges. International Marketing Review, 28(2), 132-149.

Paul, J. (2020). SCOPE framework for SMEs: A new theoretical lens for success and internationalization. European Business Review, 38(2), 219-230.

Paul, J., \& Rosado-Serrano, A. (2019). Gradual internationalization vs. born-global/international new venture models: A review and research agenda.

International Marketing Review, 36(6), 830-858. 
Prashantham, S., Kumar, K., Bhagavatula, S., \& Sarasvathy, S. D. (2019). Effectuation, network-building and internationalisation speed. International Small Business Journal, 37(1), 3-21.

Ribau, C. P., Moreira, A. C., \& Raposo, M. (2018). SME internationalization research: Mapping the state of the art. Canadian Journal of Administrative Sciences/Revue Canadienne des Sciences de l'Administration, 35, 280-303.

Sarasvathy, S. (2001). Causation and effectuation: Toward a theoretical shift from economic inevitability to entrepreneurial contingency. The Academy of Management Review, 26(2), 243-263.

Sarasvathy, S., Kumar, K., York, J. G., \& Bhagavatula, S. (2014). An effectual approach to international entrepreneurship: Overlaps, challenges, and provocative possibilities. Entrepreneurship Theory and Practice, 38(1), 71-93.

Schweizer, R. (2012). The internationalization process of SMEs: A muddling-through process. Journal of Business Research, 65(6), 745-751.

Schweizer, R., Vahlne, J.E., \& Johanson, J. (2010). Internationalization as an entrepreneurial process. Journal of International Entrepreneurship, 8(4), 343-370.

Sedziniauskiene, R., Sekliuckiene, J., Zucchella, A. (2019). Networks' impact on the entrepreneurial internationalization: A literature review and research agenda. Management International Review, 59(5), 779-823.
Spence, M., \& Crick, D. (2006). A comparative investigation into the internationalisation of Canadian and UK high-tech SMEs. International Marketing Review, 23(5), 524-548.

Thai, M. T. T., \& Chong, L. C. (2013). Dynamic experimental internationalization: Strategy of SMEs from a transition economy. Journal of International Entrepreneurship, 11(4), 370-399.

Vahlne, J., \& Johanson, J. (2017). From internationalization to evolution: The Uppsala model at 40 years. Journal of International Business Studies, 48, 1087-1102.

Vahlne, J., \& Johanson, J. (2020). The Uppsala model: Networks and micro-foundations. Journal of International Business Studies, 51, 4-10.

Weerawardena, J., Mort, G. S., Liesch, P. W., \& Knight, G. (2007). Conceptualizing accelerated internationalization in the born global firm: A dynamic capabilities perspective. Journal of World Business, 42(3), 294306.

Xie, Y. H., \& Suh, T. (2014). Perceived resource deficiency and internationalization of small- and medium-sized firms. Journal of International Entrepreneurship, 12(3), 207-229.

Yip, G. S., Gómez, J., \& Monti, J. A. (2000). The role of the internationalization process in the performance of newly internationalizing firms. Journal of International Marketing, 8(3), 10-36.

Zhao, H., \& Hsu, C.-C. (2007). Social ties and foreign market entry: An empirical inquiry. Management International Review, 47(6), 815-844. 